\title{
Importance of the geobotanical studying in agriculture (with the example of the Sugaty region)
}

\author{
Alibek Ydyrys ${ }^{1,}$, Nurshat Abdolla ${ }^{1}$, Ainur Seilkhan ${ }^{2}$, Muratzhan Masimzhan ${ }^{3}$ and Lazzat \\ Karasholakova $^{4}$ \\ ${ }^{1}$ Al-Farabi Kazakh National University, 71 al-Farabi Ave. 050040 Almaty, Kazakhstan \\ ${ }^{2}$ Department of Kazakhstan geography and ecology, Abai University, 05001013 Dostyk Ave, \\ Almaty, Kazakhstan \\ ${ }^{3}$ Department of Agrochemical, Soil Surveys and Comprehensive Survey Work-Branch of the State \\ Corporation "Government for Citizens" in Almaty, 050040 Almaty, Kazakhstan \\ ${ }^{4}$ Zhetysu State University named I. Zhansugurov, 040009 Str.I. Zhansugurov, 187A, Taldykorgan, \\ Kazakhstan
}

\begin{abstract}
This article provides an overview of the literature on the role of geobotanical research in agriculture. In it, the author describes this article, which contains opposing points of view on the problem considered in the importance of geobotanical studies of today's agricultural systems. The article discusses the problems and ways to solve the economic use of geobotany is the creation of artificial phytocenoses, as well as changing the natural ones by one or another violation of their composition and structure. Agriculture should ensure the maintenance of ecological balance in agrolandscape systems. Compliance with the requirements of environmental management, environmental protection and optimization of management of agricultural landscapes is becoming one of the main conditions for increasing the productive longevity of agricultural ecosystems and the efficiency of agricultural production.
\end{abstract}

\section{Introduction}

At now days, phytocenosis - agroecosystems has been more difficult to avoid the transformation associated with the growth of global anthropogenic pressure. Concurrently, anthropogenic factors affect all parts of ecosystems (biogeosenosis) and agroecosystems, causing changes in the living component of nature. The study of the real state of agroecosystems, their changes and stability under the load of anthropogenic factors is impossible without a comprehensive, in-depth study of them. At the same time, in any ecosystem, the phytocenosis plays two equally important roles: "independent" and as an important object of control and monitoring, and as an indicator that characterizes the actual ecological situation and any quality of the environment, taking into account the environment-forming functions and the intended use of agroecosystems. The plant

\footnotetext{
${ }^{*}$ Corresponding author: ydyrys.alibek@gmail.com
} 
component of agroecosystems exhibits specific reactions to anthropogenic effects; the composition and function of flora changes, the self-regulation of natural biogeocenoses slows down, new floristic complexes and synanthropic associations with different species composition appear, the boundaries and basic dimensions of many plant species and populations in the phytocenosis change, mainly the structure of their populations. The specifics and size of construction change, some species disappear individually. And in agricultural areas (artificial biogeocenoses) the main role in the composition of biodiversity and the preservation of biological and ecological balance are played by their components that do not directly affect agricultural production [1,2].

The study of the consequences of these changes and processes, as well as the study of the actual state of phytocenoses, their dynamic changes, tolerance, genesis today to preserve and protect biodiversity, the sustainability of natural and artificial phytocenoses (agriculture) also important for. However, the current scientific community does not pay enough attention to the study of these issues, only a few scientific papers are devoted to the study of some aspects of these issues [3,4]. Thus, knowledge about the impact of anthropogenic changes on the phytocenoses of agro-ecosystems is still insufficient. In addition, agricultural systems usually have a stable dynamics of vegetation characteristics, such as natural biogeocenoses. Therefore, taking into account the anthropogenic factor as the main factor influencing the vegetation cover, it is possible to make a modern ecological and phytocenological assessment of agro-ecosystems around settlements.

Today, scientists often use geobotanic methods to research the population of rare and endemic plants [5, 6]. As well as in demanding methods for increasing new grain crops [7]. Research in the field of agrosystems and biogeocenology has confirmed that the fertility of agricultural lands and soils can be maintained only when the natural conditions for soil biota development and soil formation are created and the main soil-forming parts, perennial plants and microbiocenoses are active. Biomorphological features of the root system of perennial grasses play an important role in soil formation. The root mass of perennial herbaceous plants in the natural biogeocenosis exceeds the mass of their aboveground part [8]. Perennial herbaceous plant communities perform important ecological, industrial and phytocenotic functions in the agricultural system and affect the ecological condition of the environment, as well as promote the formation, storage, circulation and accumulation of organic matter on the earth's surface. Perennial phytocenoses are needed to restore the soil layer, which will inevitably disappear when growing annual crops using technical equipment and chemicals in agriculture. In many cases, perennial cereals, along with perennial legumes, play an important role in soil formation, providing the soil layer with sufficient humus and minerals to form the soil structure and forming a sufficiently strong structural soil layer for the environment. This feature of herbal mixtures derived from perennial cereals and legumes allows you to control the structure and fertility of the soil. At the same time, the study of biohumus from natural organic substances opens a new direction in soil fertility in agricultural systems [9]. Dohman and Porokhovnik argue, for example, that geobotanical elements can be found in the works of the famous Russian agronomist G. I. Engelman, especially in his book Theoretical and Practical Guide to Drainage of Lands [10]. A spontaneous examination of various problems (even with the advent of terminology) of nascent science in the bowels of another science is a common occurrence in the history of knowledge. The same elements can be found, for example, in German agronomic (and forestry) literature from the beginning of the last century. But they did not determine the origin of the early German geobotany. It is appropriate to recall the words of D. I. Mendeleev that priority does not belong to the one who made this or that assumption or introduced any concept, but to the one who carried out a revolution in science. Moreover, such revolutionaries of science come to the substantiation of a new 
science, using early information, generalizing them and interpreting them in a new way [11, $12]$.

\section{Materials and Methods}

The object of our research was pastures and filed lands of around the Sugaty Mountain (Kazakhstan, Almaty region), which were used for agriculture. Research work consists of methods of plant-locating by route-reconnaissance, using GPS navigation. Geobotanical descriptions were performed by the conventional methods. The study population was carried out according to the traditional methods of Rabotnov T. A. [13]. The isolation and characterization of age made use of the procedural provisions in the works of Rabotnov $\mathrm{T}$. A. and Uranov A. A. [14].

\section{Results and discussion}

Geobotanical research is very important in the development of pastures and field lands. According to the distribution of different plant groups, the geobotanist identifies useful species of plants, each of which is divided into separate groups, requiring specific measures for the cultivation or use of peat reserves for specific crops. General information on the geobotanical map and phytocenosis of agricultural lands is therefore a necessary basis for its development.



Fig. 1. The most common plant families of agrobiocenosis of the Sugaty Mountains

In total, 182 species of higher plants belonging to 136 relatives and 38 genera of pasture and filed agrobiocenosis around Sugaty Mountain were registered. The coefficient of kinship, the ratio of the number of species to relatives as a percentage is $79.01 \%$, and the ratio of dicotyledonous plants to monocotyledons is $13.7 \%$. The systematic composition of the plant community in the agricultural lands of the Sugaty Mountains is as follows: bare species - 1 species, flowering plants - 181 species. Of the flowers, 29 species belong to the class of monocotyledons, 151 - to the class of dicotyledons. The most common families are Asteraceae (28 species or $15.5 \%$ ) and Chenopodiaceae (20 species or $11.0 \%$ ). The third 
place belongs to the families Poaceae (19 species or 10.5\%) and Brassicaceae (15 species or $8.3 \%)$. In fourth place is the family Caryophyllaceae (12 species or $6.6 \%)$. The fifth position is occupied by the family Fabaceae (10 species or $5.5 \%)$, the sixth place - the family Rosaceae and Lamiaceae, with 7 species each (3.9\%). 118 species or $65.2 \%$ belong to these 8 genera (Fig 1.). In other families the number of species is small. About half of the plants found in this area, therophytes - annual plants with short development cycles. In second place are hemicryptophytes, perennial herbaceous plants. In the third and fourth places are shrubs ( 8 species) and semi-shrubs ( 3 species). Shrubs and semi-shrubs are found in only one species. In terms of ecological types, xerophytes (70 species) and mesophytes (30 species) are widespread here. According to the above data, due to external factors (strong anthropogenic impact, animal husbandry, harvesting as a raw material for medicine, animal nutrition, etc.), the pastures of the study area can be classified as regressive. And a few weeds are found in the fields, some of them are medicinal plants used in folk medicine, although they are harmful to agriculture. For example species of Artemisia, Taraxcaum and Lappula, Agrimonia.

\section{Conclusion}

The vegetative component of agro-ecosystems experiences increasing anthropogenic pressure every year. In addition, the objective indicators of the condition of the stand: species composition, the ratio of ecological and coenotic groups, the number of species per unit, plant height and condition of the grass cover are affected by anthropogenic factors. Such changes, as mentioned in the content of the above article, lead to changes in the phytosenosis, which is most important for the agro-system. Therefore, in the field of agriculture, geobotanical research of phytocenoses plays an important role in the preservation of natural (pasture) or artificial (crop) biogeocenoses of agricultural land. And mapping of agricultural lands through geobotanical research is one of the best methods that can be used to preserve the ecological environment, productivity and soil fertility.

\section{References}

1. Dariusz Jaskulski, Iwona Jaskulska Plant. Diversity in Agroecosystems and Agricultural Landscapes, (2012) DOI: 10.5772/47729

2. Seilkhan A.S., Mizadinov R.A., Mizadinov, I.R., Kizdarbekova, M.A. International Multidisciplinary Scientific GeoConference Surveying Geology and Mining Ecology Management, SGEM, 2, 195-208 (2016)

3. A. Begenov, N. Mukhitdinov, A. Ametov, S. Nazarbekova, A. Kuatbayev, B. Tynybekov, K. Abidkulova, A. Ydyrys. World Applied Sciences Journal: IDOSI Publications, 30(1), 105-109 (2014)

4. A. Ydyrys, N. Mukhitdinov, A. Ametov, B. Tynybekov, A. Akhmetova, K. Abidkulova. World Appl Sc J, 26 (7), 934-940 (2013)

5. Aigul Akhmetova, Nashtay Mukhitdinov, Alibek Ydyrys, Pakistan Journal of Botany, 47(2), $511-515$ (2015)

6. A.B. Akhmetova, N.M. Mukhitdinov, A. Ydyrys, A.A. Ametov, Z.A. Inelova, M. Öztürk. Journal of Animal and Plant Sciences, 28(5), 1400-1404 (2018)

7. E.A. Bukenova, Zh.M. Bassygarayev, A.B. Akhmetova, Zh.K. Zhunusbayeva, A. Ydyrys. Research on Crops, 20(1), 210-214 (2019) 
8. V.M. Kosolapov, I.A. Trofimov, L.S. Trofimova, E.P. Yakovleva. Vestnik Rossiyskoy akademii sel'skokhozyaystvennykh nauk, 1, 16-18 (2012)

9. Alibek Ydyrys, Birlikbay Yeszhanov, Nurlan Baymurzaev, Tilek Baidaulet. E3S Web of Conferences, 169, 02012 (2020)

10. G.I. Dohman. Botanical Journal, 4, 35-41 (1962)

11. G.I. Dohman, P.E. Porokhovnik. Nerd. Zh., 38(2), (1953)

12. G. Engelman. Theoretical and practical guide to drainage of land or Indication of the reasons giving rise to excessive sputum in the soil and producing swell, and swamps (SPb., Shnor, 1810)

13. T.A. Rabotnov. Geobotany, 6, 70-205 (1960)

14. A.A. Uranov. Ontogeny and age composition of populations. Ontogeny and age structure of populations of flowering plants, (Moscow, 1967) 